\title{
Upaya Peningkatan Hasil Belajar Siswa Melalui Penerapan Metode Resitasi dengan Media Gambar pada Mata Pelajaran IPA Materi Struktur dan Fungsi Tumbuhan di Kelas VIII-1 Semester 1 SMPN 4 Bolo Tahun Pelajaran 2020/2021
}

\author{
Kasmir \\ SMP Negeri 4 Bolo, Bima, Indonesia \\ *Coresponding Author: kasmirk2019@gmail.com \\ Dikirim: 19-08-2021; Direvisi: 24-10-2021; Diterima: 25-10-2021
}

\begin{abstract}
Abstrak: Rendahnya hasil belajar pada materi struktur dan fungsi tumbuhan pembelajaran IPA di kelas VIII-1 SMPN 4 Bolo semester 1 tahun pelajaran 2020/2021 dengan rata-rata nilai formatif tes siswa berada di titik 75.00 dan ketuntasan klasikal 78.00\%, membutuhkan tindakan perbaikan pembelajaran. Penelitian perbaikan pembelajaran ini bertujuan menjelaskan dan menganalisis dampak penerapan metode resitasi dengan media gambar dalam meningkatkan hasil belajar siswa dan kinerja guru dalam pembelajaran IPA pada materi struktur dan fungsi tumbuhan di kelas VIII-1 SMPN 4 Bolo semester 1 tahun pelajaran 2020/2021. Subyek dalam penelitian ini adalah siswa kelas VIII-1 berjumlah 30, terdiri dari 13 orang laki-laki dan 17 orang perempuan. Kriteria keberhasilan penelitian ditetapkan dalam hal prestasi belajar adalah $\geq 80.00$ dengan ketuntasan klasikal $\geq 85.00 \%$, dan kinerja guru untuk perencanaan dan pelaksanaan pembelajaran adalah 92.00. Setelah pelaksanaan tindakan di siklus I, hasil pos tes menunjukkan bahwa hasil belajar siswa ratarata 78.25. Nilai rata-rata ini telah mengalami peningkatan $(+3.25)$ dan persentase ketuntasan meningkat $(+2.00)$ dibanding sebelum diadakan perbaikan. Sementara itu, kinerja guru untuk perencanaan pembelajaran mencapai nilai $91.80(+0.30)$ dan pelaksanaan pembelajaran ada di skor 91.88 (+0.18) pada siklus I. Prestasi belajar siswa dan kinerja guru masih belum sesuai kriteria keberhasilan sehingga perlu dilanjutkan ke siklus selanjutnya. Pada siklus II, hasil pos tes menunjukkan bahwa hasil belajar siswa rata-rata 85.55 (+7.30) dengan persentase ketuntasan klasikal $90.75 \%$ (10.75). Persentase ini telah memenuhi indikator kinerja yakni $\geq 85.00 \%$. Dengan demikian pada siklus II ini telah berhasil mencapai indikator yang ditetapkan yakni rata-rata $\geq 80.00$ dan persentase ketuntasan $\geq 85.00 \%$. Sementara, skor kinerja guru menunjukkan skor kemampuan perencanaan pembelajaran pada angka 93.30 $(+1.50)$ dan kemampuan pelaksanaan pembelajaran pada skor $93.00(+1.42)$. Dan skor yang diperoleh di siklus II ini berhasil memenuhi kriteria keberhasilan yang ditetapkan. Dengan demikian, penerapan metode resitasi dengan media gambar dalam meningkatkan hasil belajar siswa dan kinerja guru dalam pembelajaran IPA pada materi struktur dan fungsi tumbuhan di kelas VIII-1 SMPN 4 Bolo semester 1 tahun pelajaran 2020/2021sukses pada siklus II, dan penelitian tindakan berhasil.
\end{abstract}

Kata Kunci: penerapan metode resitasi; media gambar

Abstract: The low learning outcomes on the material structure and function of science learning plants in class VIII-1 SMPN 4 Bolo semester 1 for the 2020/2021 school year with an average formative test score of students at 75.00 and classical completeness $78.00 \%$, required corrective learning actions. This learning improvement research purposed to explain and analyze the impact of applying the recitation method with image media in improving student learning outcomes and teacher performance in science learning on the material structure and function of plants in class VIII-1 of SMPN 4 Bolo semester 1 of the 2020/2021 academic year. The subjects in this study were 30 grade VIII-1 students, consisting of 13 boys and 17 girls. The criteria for the success of the research in terms of learning 
achievement were 80.00 with classical completeness $85.00 \%$, and teacher performance for planning and implementing learning was 92.00. After the implementation of the actions in the first cycle, the results of the post-test showed that the average student learning outcomes were 78.25. This average value has increased $(+3.25)$ and the percentage of completeness has increased $(+2.00)$ compared to before the improvement. Meanwhile, the teacher's performance for lesson planning reached a score of $91.80(+0.30)$ and the implementation of learning was at a score of $91.88(+0.18)$ in the first cycle. Although the percentage of classical completeness had reached the criteria, the student achievement and teacher performance still did not meet the criteria. So it needs to be continued to the next cycle. In the second cycle, the results of the post-test showed that the average student learning outcomes were $85.55(+7.30)$ with a classical mastery percentage of $90.75 \%(10.75)$. This percentage has met the performance indicator of $85.00 \%$. Thus, in the second cycle, it has succeeded in achieving the specified indicators, namely an average of 80.00 and a percentage of completeness $85.00 \%$. Meanwhile, the teacher's performance score showed the learning planning ability score at $93.30(+1.50)$ and the learning implementation ability at 93.00 $(+1.42)$. And the scores obtained in the second cycle managed to meet the established success criteria. Thus, the application of the recitation method with image media in improving student learning outcomes and teacher performance in science learning on the material structure and function of plants in class VIII-1 SMPN 4 Bolo semester 1 of the 2020/2021 academic year was successful in cycle II, and action research was successful.

Keywords: implementation of recitation method; image media

\section{PENDAHULUAN}

Metode pembelajaran merupakan bagian penting dalam pengelolaan pembelajaran, yang mempengaruhi terhadap pencapaian tujuan pembelajaran. Pemilihan metode pembelajaran yang tepat akan sangat membantu dalam prosesnya. Tardif dalam Muhibbin Syah (1995) menjelaskan bahwa metode diartikan sebagai cara yang berisi prosedur baku untuk melaksanakan kegiatan penyajian materi pelajaran kepada siswa. Berdasarkan pendapat diatas menunjukkan bahwa metode pembelajaran adalah cara memproses kegiatan belajar supaya siswa dapat berinteraksi secara aktif sehingga terjadi perubahan pada dirinya sesuai dengan tujuan belajar yang direncanakan. Metode belajar sebagai alat berkomunikasi dalam proses belajar merupakan unsur penting yang mempengaruhi pencapaian tujuan belajar.

Dengan metode belajar akan tertuntun proses belajar, akan terbangkit perhatian dan minat siswa, akan tercipta interaksi belajar atau akan terjadi proses perubahan individu siswa, sesuai dengan tujuan belajar yang direncanakan. Oleh karena itu penentuan metode dalam suatu kegiatan pembelajaran, sangat berpengaruh terhadap terciptanya kondisi pembelajaran yang kondusif, menyenangkan, sehingga kegiatan pembelajaran (instructional activities) dapat berlangsung secara efektif dan efisien dalam memfasilitasi siswa untuk dapat mencapai tujuan pembelajaran yang diharapkan.

Dalam konteks pembelajaran tidak ada satupun metode yang dianggap paling baik, demikian pula tidak ada satupun metode yang dianggap paling buruk, karena semua metode pasti memiliki kelebihan dan kekurangan masing-masing. Satu metode yang berhasil diterapkan pada mata pelajaran tertentu, belum tentu akan berhasil bila diterapkan dengan mata lainnya. Pembelajaran IPA misalnya karena mata pelajaran tersebut memiliki karakteristik yang berbeda dengan mata pelajaran 
lain maka apa yang berhasil di mata pelajaran lain belum tentu berhasil bila diterapkan pada pembelajaran IPA. Bahkan dalam satu mata pelajaran di kelas yang sama, metode yang berhasil diterapkan pada Kompetensi Dasar tertentu tertentu belum tentu berhasil diterapkan pada Kompetensi Dasar yang lainnya.

Pada materi sebelumnya peneliti menerapkan metode ceramah dan bermain peran, akan tetapi metode tersebut kurang berhasil. Peneliti telah mencoba melakukan metode tanya jawab pada awal pembelajaran materi baru. Ternyata hasilnya tidak seperti yang peneliti harapkan. Pelaksanaan metode tanya jawab tersendat-sendat, karena materi struktur dan fungsi tumbuhan tenyata kurang tepat dengan metode tanya jawab, sehingga pembelajaran tidak berjalan seperti yang direncanakan, waktu yang digunakan telalu lama. Dampaknya lebih lanjut hasil belajar siswa rendah, hal ini ditunjukkan dengan rendahnya rata-rata nilai formatif tes siswa 75.00 dengan ketuntasan klasikal $78.00 \%$. Hasil pos tes yang peneliti lakukan masih belum mencapai Kriteria Ketuntasan Minimal (KKM) yang ditentukan yakni rata-rata $\geq 80.00$ dengan ketuntasan klasikal $\geq 85.00 \%$. Demikian pula kinerja guru yang diukur untuk kemampuan perencanan dan pelaksanaan pembelajaran, hasilnya rendah. Nilai untuk perencanaan pembelajaran adalah 91.50 dan untuk pelaksanaan pembelajaran yaitu 91.70. Nilai ini dibawah indikator kinerja guru yang ditetapkan yakni untuk perencanaan pembelajaran $\geq 92.00$ dan untuk pelaksanaan pembelajaran $\geq 92.00$. Dari hasil refleksi pra-perbaikan tersebut permasalahan dapat diidentifikasi, antara lain: 1) metode tanya jawab, yang diterapkan dalam proses pembelajaran materi struktur dan fungsi tumbuhan tidak efektif, 2) proses pembelajaran memakan waktu melebihi yang direncanakan, dan 3) hasil belajar siswa yang rendah.

Maka, masalah pembelajaran perlu diberikan tindakan melalui metode pembelajaran lain, yakni metode yang membutuhkan campur tangan guru, peranan guru yang lebih banyak lagi, sekaligus campur tangan guru dalam mendesain penilaian pembelajaran sebagai bagian dari proses pembelajaran. Tidak cukup sampai disitu, guru juga perlu secara sitematis mempersiapkan materi pembelajaran dengan cermat. Metode yang memiliki karakteristik yang memungkinkan guru lebih intensif dalam mengelola pembelajaran sesuai materi tersebut adalah adalah metode resitasi dengan media gambar. Metode resitasi dengan media gambar menurut Syaiful (2008), resitasi adalah cara penyajian bahan dimana guru memberikan tugas tertentu agar siswa melakukan kegiatan belajar, kemudian belajar dan harus dipertanggung jawabkannya.

Menurut Darajat (2011), resitasi adalah metode pembelajaran yang menekankan pada pemberian tugas oleh guru kepada siswa untuk menyelesaikan sejumlah kecakapan, keterampilan tertentu. Dan, dalam pelaksanaan metode pembelajaran, media juga berperan dalam kelancaran dan nilai tambah pada proses pembelajaran. Media gambar dalam konteks penelitian ini dianggap sesuai dengan materi pembelajaran.

Dalam metode resitasi, peran guru lebih besar, sejalan dengan besarnya tanggung jawab siswa, dan didukung media gambar, sehingga mendorong tingginya aktivitas siswa karena disertai dengan tanya jawab dan penugasan dengan materi yang telah diolah matang oleh guru. Materi dan tugas secara sistematis tersaji dalam pembelajaran yang terolah, dipersiapkan dengan baik menungkinkan siswa dapat memahami materi dam mengerjakan tugas yang kompleksitasnya tinggi dengan baik. 
Karena materi struktur dan fungsi tumbuhan berkaitan dengan beberapa bagian dari tumbuhan yang berbeda, ada yang dapat diamati langsung dan ada yang perlu media, maka dipilihlah media gambar untuk mendukung efektivitas metode resitasi. Dengan demikian proses pembelajaran berjalan secara efektif sehingga hasil belajar siswa dapat meningkat.

\section{KAJIAN TEORI}

\section{A. Metode resitasi}

Metode resitasi atau penugasan adalah metode pembelajaran yang menekankan pada pembacaan, pengulangan, pengujian, dan pemeriksaan atas diri sendiri melalui sejumlah tugas yang diberikan oleh guru kepada siswa di luar jam sekolah dalam rentang waktu tertentu dan hasilnya dipertanggung jawabkan kepada guru dengan tujuan untuk merangsang siswa untuk aktif belajar baik secara individu maupun kelompok.

Bentuk tugas yang dapat diberikan adalah tugas-tugas dalam bentuk daftar sejumlah pertanyaan mengenai mata pelajaran tertentu, atau satu perintah yang harus dibahas dengan diskusi atau perlu dicari uraiannya pada buku pelajaran. Masalah tugas yang dilaksanakan oleh siswa dapat dilakukan luar kelas, misalnya di halaman sekolah, di laboratorium, di perpustakaan, di bengkel, maupun di rumah siswa asal tugas itu dapat dikerjakan.

Berikut definisi dan pengertian metode pembelajaran resitasi dari beberapa sumber. Menurut Majid (2013), resitasi adalah metode belajar yang mengkombinasikan penghafalan, pembacaan, pengulangan, pengujian, dan pemeriksaan atas diri sendiri. Menurut Djamarah dan Zain (2010), resitasi adalah metode penyajian bahan dimana guru memberikan tugas tertentu agar siswa melakukan kegiatan belajar yang bertujuan untuk merangsang anak agar aktif belajar, baik secara individual ataupun secara kelompok. Menurut Slameto (1991), resitasi adalah cara penyajian bahan pelajaran yang memberikan tugas kepada siswa untuk dikerjakan di luar jadwal sekolah dalam rentang waktu tertentu dan hasilnya dipertanggung jawabkan kepada guru. Menurut Ahmadi dan Prasetya (1997), resitasi adalah metode pengerjaan rumah yaitu murid diberi tugas di luar jam pelajaran, dimana anak-anak dapat mengerjakan tugasnya tidak hanya di rumah, tetapi dapat di perpustakaan, di laboratorium, di kebun percobaan dan sebagainya untuk dibertanggung jawabkan kepada guru. Menurut Syaiful (2008), resitasi adalah cara penyajian bahan dimana guru memberikan tugas tertentu agar siswa melakukan kegiatan belajar, kemudian belajar dan harus dipertanggung jawabkannya. Menurut Darajat (2011), resitasi adalah metode pembelajaran yang menekankan pada pemberian tugas oleh guru kepada siswa untuk menyelesaikan sejumlah kecakapan, keterampilan tertentu.

\section{Metode resitasi dengan media gambar}

Menurut Djamarah dan Zain (2010), tugas dan resitasi merangsang anak untuk aktif belajar, baik secara individu maupun secara kelompok. Melalui metode resitasi dengan media gambar siswa kesempatan untuk saling membandingkan dengan hasil pekerjaan orang lain, dapat mempelajari dan mendalami hasil uraian orang lain. Dengan demikian akan memperluas, memperkaya dan memperdalam pengetahuan serta pengalaman siswa. 
Menurut Hamdayama (2014), metode pemberian tugas belajar atau resitasi memiliki beberapa tujuan, antara lain: 1) memperdalam pengertian siswa terhadap pelajaran yang telah diterima, 2) melatih siswa ke arah belajar mandiri, 3) siswa dapat membagi waktu terluang untuk menyelesaikan tugas, 4) melatih siswa untuk menemukan sendiri cara-cara yang tepat untuk menyelesaikan tugas, dan 5) memperkaya pengalaman-pengalaman disekolah melalui kegiatan-kegiatan di luar kelas.

Metode resitasi merupakan metode yang dapat mengaktifkan siswa untuk mempelajari sendiri sendiri suatu masalah dengan jalan membaca sendiri, mengerjakan soal sendiri, sehingga apa yang mereka pelajari dapat mereka rasakan berguna untuk mereka dan akan lebih lama mereka ingat. Penggunaan metode resitasi dengan media gambar (tugas), diberikan dengan harapan agar siswa memiliki hasil belajar yang lebih maksimal.

\section{Jenis-jenis metode resitasi}

Menurut Nasution (2000), terdapat dua jenis metode resistasi, yaitu:

a. Penugasan Individu, yaitu suatu penugasan yang dibebankan kepada masingmasing siswa. Tugas individual lebih ditekankan kepada pembinaan kognitifafektif-psikomotor siswa secara individual. Melalui tugas individual siswa dituntut menurut kesanggupan dan kerajinan masing-masing. Namun demikian, siswa tetap diberi kesempatan untuk berdialog dengan siswa lain, namun tetap tugas yang harus diselesaikannya bersifat perorangan.

b. Penugasan Kelompok. Penugasan kelompok adalah suatu langkah yang digunakan oleh pendidik untuk membantu siswa supaya mereka mampu melakukan kerja sama di dalam kelompok-kelompok yang sengaja dibentuk guna melaksanakan kegiatan pembelajaran tertentu yang ditugaskan kepada para siswa. Siswa didorong atau dikehendaki untuk bekerja sama pada suatu tugas dan mereka harus mengkoordinasi usahanya menyelesaikan tugasnya. Tugas-tugas itu dikerjakan dalam kelompok secara bergotong royong.

\section{Langkah-langkah metode resitasi}

Menurut Djamarah dan Zein (2010), langkah-langkah metode resitasi dapat dilakukan melalui beberapa langkah atau fase, yaitu sebagai berikut:

a. Fase pemberian tugas, dimana tugas yang diberikan kepada siswa hendaknya mempertimbangkan tujuan yang akan dicapai, jenis tugas yang sesuai dengan kemampuan siswa, serta adanya petunjuk yang dapat membantu dan disediakan waktu yang cukup untuk mengerjakan tugas tersebut.

b. Fase pelaksanaan tugas, dimana dalam fase ini diberikan bimbingan atau pengawasan oleh guru, diberikan dorongan sehingga anak mau melaksanakan, diusahakan atau dikerjakan oleh anak sendiri, mencatat semua hasil yang diperoleh dengan baik dan sistematis.

c. Fase pertanggung jawaban tugas, saat siswa melaporkan baik secara lisan atau tertulis dari apa yang telah dikerjakan, ada tanya jawab dan diskusi, penilaian hasil pekerjaan siswa baik dengan tes atau non-tes atau cara lainnya.

Sedangkan menurut Shalahuddin (1987), metode resitasi akan lebih efektif apabila dilaksanakan dengan langkah-langkah sebagai berikut: 1) tugas yang akan dikerjakan murid harus jelas dan tegas pembatasannya, dengan demikian murid tidak ragu-ragu dalam mengerjakan tugasnya, 2) tugas yang diberikan harus sesuai dengan taraf perkembangan kecerdasan maupun minta murid, 3) waktu untuk mengerjakan 
tugas harus jelas, 4) adakan kontrol yang sistematis, sehingga mendorong anak untuk bekerja dengan sungguh-sungguh, 5) tugas yang diberikan hendaknya dapat memperkaya pengalaman murid baik untuk di sekolah di rumah maupun di masyarakat, dan 6) tugas yang diberikan hendaknya dapat bermanfaat baik untuk kebutuhan murid pada saat sekarang maupun yang akan datang.

\section{Kelebihan dan Kekurangan metode resitasi}

Setiap metode pembelajaran umumnya memiliki kelebihan dan kekurangan masing-masing begitu juga dengan metode pembelajaran resitasi. Menurut Hardini dan Puspitasari (2012), kelebihan dan kekurangan metode resitasi dengan media gambar adalah sebagai berikut:

a. Kelebihan metode resitasi, adalah: 1) memupuk rasa percaya diri sendiri, 2) memberi kebiasaan siswa untuk mencari, mengelola informasi dan mengkomunikasikan sendiri, 3) mendorong belajar, sehingga tidak mudah bosan, 4) membina tanggung jawab dan disiplin siswa, 5) mengembangkan kreativitas siswa, dan 6) mengembangkan pola berpikir dan ketrampilan siswa.

b. Kekurangan metode resitasi, antara lain: 1) guru tidak dapat mengontrol apakah siswa telah mengerjakan tugas dengan benar, 2) guru sulit membedakan siswa yang aktif dan pasif jika tugas diberikan secara berkelompok, 3) tidak mudah memberikan tugas yang sesuai dengan perbedaan keadaan individu siswa, dan 4) tugas yang diberikan tidak boleh terlalu mudah atau terlalu sukar namun perlu dimodifikasi agar tidak dianggap memudahkan atau mempersulit siswa dalam mengerjakannya.

Tugas merupakan refleksi kehidupan. Setiap orang dalam hidupnya sehari-hari tak terlepas dari tugas-tugas yang seyogyanya dikembangkan dalam kehidupan di sekolah sebagai persiapan memasuki dunia kerja yang penuh denan berbagai tugas kelak. Sebab barang tentu tugas yang diberikan adalah yang berhubungan dengan topic yang sedang dan atau dipelajarai.

\section{B. Media Pembelajaran}

Media Pembelajaran merupakan sesuatu hal yang dapat digunakan pada saat proses belajar mengajar. Beberapa ahli mendefinisikan pengertian media menurut pendapatnya masing-masing. Anitah (2009:1) menjelaskan bahwa, "Kata media berasal dari bahasa latin, yang merupakan bentuk jamak dari kata medium, yang berarti sesuatu yang terletak di tengah (antara dua pihak atau kutub) atau suatu alat. Media juga dapat diartikan sebagai perantara atau penghubung antara dua pihak, yaitu antara sumber pesan dengan penerima pesan atau informasi. Oleh karena itu, media pembelajaran berarti sesuatu yang mengantarkan pesan pembelajaran antara pemberi pesan kepada penerima pesan".

\section{Media Gambar}

Berdasarkan kamus besar bahasa Indonesia, gambar adalah tiruan barang (orang, binatang, tumbuhan dan sebagainya). Gambar merupakan media visual dua dimensi di atas bidangnya yang tidak transparan. Dale (Dalam Subana, 1998 : 322) menjabarkan bahwa guru dapat menggunakan gambar untuk memberikan gambaran tentang sesuatu sehingga penjelasannya lebih kongkrit dari pada bila diuraikan dengan kata-kata. Melalui gambar, guru dapat menterjemahkan ide-ide abstrak dalam bentuk yang realistis. Dalam membuat petunjuk penggunaan suatu alat dengan bahasa yang baik dan benar, siswa bisa menyusun kata-kata dari gambar yang dilihat. 
Subana (1998 : 322) menjelaskan manfaat gambar sebagai media pembelajaran antara lain : 1) menimbulkan daya tarik pada diri siswa, 2) mempermudah pengertian atau pemahaman siswa, 3) mempermudah pemahaman yang sifatnya abstrak, 4) memperjelas dan memperbesar bagian yang penting atau yang kecil sehingga dapat diamati, dan 5) menyingkat suatu uraian. Informasi yang diperjelas dengan kata-kata mungkin membutuhkan uraian panjang. Gambar sebagai media pembelajaran juga mempunyai beberapa syarat yang harus dipenuhi agar menjadi media pembelajaran yang baik (Subana, 1998), sebagai berikut: 1) bagus, jelas, menarik, dan mudah dipahami, 2) cocok dengan materi pembelajaran, 3) benar dan otentik, artinya menggambarkan situasi yang sebenarnya, 4) sesuai dengan tingkat umur dan kemampuan siswa, 5) walaupun tidak mutlak baiknya gambar menggunakan warna yang menarik sehingga lebih realitas dan merangsang minat siswa untuk mengamatinya, 6) perbandingan ukuran gambar harus sesuai dengan ukuran objek yang sebenarnya, agar siswa lebih tertarik dan memahami gambar, hendaknya menunjukkan hal-hal yang sedang mereka perbuat, dan 7) gambar yang dipilih hendaknya mengandung nilai-nilai murni dalam kehidupan sosial.

Selanjutnya, Subana (1998) menjelaskan gambar sebagai media pembelajaran mempunyai kelebihan dan kelemahan. Kelebihan yang dimiliki gambar sebagai media pembelajaran, antara lain: 1) gambar mudah diperoleh pada buku, majalah, koran, album foto dan sebagainya, 2) dapat menterjemahkan ide-ide abstrak dalam bentuk yang lebih nyata, 3) gambar mudah dipakai karena tidak membutuhkan peralatan, 4) gambar relatif mudah, dan 5) gambar dapat digunakan banyak hal dan berbagai disiplin ilmu. Sementara, kekurangan gambar sebagai media pembelajaran dapat ditunjukkan sebagai berikut: 1) karena berdimensi dua, gambar sukar untuk melukiskan bentuk sebenarnya (yang berdimensi tiga), 2) gambar tidak dapat memperlihatkan gerak seperti halnya gambar hidup, 3) siswa tidak selalu dapat menginterpretasikan isi gambar, dan 4) kadang-kadang terlalu kecil untuk dipertunjukkan di kelas yang lebih besar.

\section{METODE PENELITIAN}

Penelitian didesain dalam bentuk penelitian tindakan kelas, yang melibatkan siswa kelas VIII-1 semester 1 SMPN 4 Bolo berjumlah 30, terdiri dari 13 orang lakilaki dan 17 orang perempuan. Adapun rata-rata intake siswa adalah cukup, fasilitas sekolah untuk proses pembelajaran baik. Materi yang diajarkan dalam tindakan pembelajaran adalah struktur dan fungsi tumbuhan.

Penelitian diformat ke dalam siklus yang terdiri dari 4 (empat) tahapan utama yakni: perencanaan; penggunaan tindakan; observasi dan refleksi. Data berupa prestasi belajar siswa dan kinerja guru dibandingkan dengan kriteria keberhasilan yang telah ditentukan, yaitu: prestasi belajar atau rata-rata nilai pos tes siswa adalah $\geq 80.00$ dengan ketuntasan klasikal $\geq 85.00 \%$, dan kinerja guru untuk perencanaan $\geq 92.00$ dan pelaksanaan pembelajaran adalah $\geq 92.00$. Siklus selanjutnya dilakukan jika kriteria keberhasilan belum dicapai dengan baik. Adapun data prestasi belajar dan kinerja guru diperoleh melalui instrument tes dan lembar observasi kegiatan guru. 


\section{HASIL DAN PEMBAHASAN}

\section{Siklus I}

Pelaksanaan perbaikan pembelajaran berdasarkan hasil refleksi diri guru pada proses pembelajaran sebelumnya yakni sebelum melaksanakan perbaikan pembelajaran dalam siklus. Dalam pra siklus guru melaksanakan pembelajaran tujuannya untuk mengetahui kemampuan awal siswa dalam pemahaman tentang struktur dan fungsi tumbuhan.

Setelah kemampuan pra-siklus diketahui, guru merencanakan pembelajaran dengan metode alternative yang dipilih, yaitu: metode resitasi. Persiapan pelaksanaan tindakan dimulai dengan menyusun Rencana Perbaikan Pembelajaran (RPP) dengan mengintegrasi metode resitasi dalam pembelajaran IPA. Metode resitasi dengan media gambar dalam perencanaan penekanan pada penyiapan materi dan tugas-tugas secara sitematis, bergradasi, dari yang sederhana ke yang lebih kompleks, dari yang mudah ke yang lebih sulit, dari tugas kelompok ke tugas individual yang sistematis dirangkum dari berbagai sumber belajar, dalam hal ini dilengkapi dengan materi struktur dan fungsi tumbuhan yang relefan kemudian diolah dan dijadikan materi bahan ajar yang komprehensif dalam ditunjang dan dilengkapi media gambar yang diperlukan dengan lengkap dan detail seperti berikut:
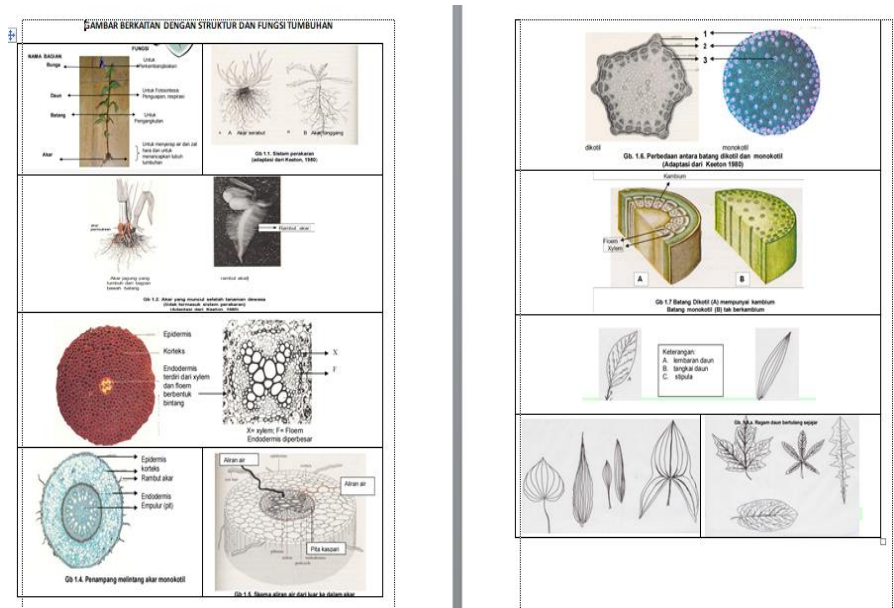

Gambar 1. Contoh gambar struktur dan fungsi tumbuhan

Gambar yang lengkap menjadi penting karena dalam proses pembelajaran gambar berperan strategis. Gambar perlu dicetak secukupnya yang akan dibagikan kepada seluruh kelompok, pada tugas kelompok (tugs I) dan kepada seluruh siswa (tugas individdual, tugas II). Penyiapan materi dan penyusunan tugas ini menjadi kunci keberhasilan penerapan metode ini. Kelengkapn materi dan tugas menjadi salah satu kunci keberhasilanya.

Hasil pelaksanaan tindakan siklus I untuk prestasi belajar dan ketuntasan klasikal dapat dilihat pada Tabel 1.

Tabel 1. Prestasi belajar siswa pada siklus I

\begin{tabular}{ccc}
\hline & Pra Siklus & Siklus I \\
\hline Nilai Rata-rata Pos Tes & 75.00 & 78.25 \\
\hline$\%$ Ketuntasan Belajar Klasikal & 78.00 & 80.00 \\
\hline
\end{tabular}


Hasil pos tes siklus I diatas menunjukkan bahwa hasil belajar siswa rata-rata 78.25. Meskipun nilai rata-rata ini telah mengalami peningkatan $(+3.25)$ dibanding sebelum diadakan perbaikan, akan tetapi nilai ini belum memenuhi indikator kinerja yang ditetapkan yakni rata-rata $\geq 80.00$. Persentase ketuntasan $80.00 \%$ telah mengalami peningkatan $(+2.00)$ dibanding sebelum diadakan perbaikan.

Sementara itu, performansi guru dalam perencanaan dan pelaksanaan pembelajaran dapat diamati dalam Tabel 2.

Tabel 2. Kinerja guru pada siklus I

\begin{tabular}{lcc}
\hline & Pra Siklus & Siklus I \\
\hline Kemampuan Perencanaan Pembelajaran & 91.50 & 91.80 \\
\hline Kemampuan Pelaksanaan Pembelajaran & 91.70 & 91.88 \\
\hline
\end{tabular}

Skor kinerja guru dalam perencanaan pembelajaran pada siklus I mencapai 91.80, dan ini meningkat (+0.30) dibanding prasiklus. Kinerja guru dalam pelaksanaan pembelajaran pada siklus I berada di angka 91.88, juga mengalami peningkatan $(+0.18)$ dari sebelum perbaikan.

Belum tercapainya indikator prestasai belajar siswa disebabkan guru belum mampu melaksanakan seluruh langkah-langkah yang ditetapkan dalam RPP. Dengan demikian secara substansial Rencana Pembelajaran tidak perlu diganti atau direvisi. Yang perlu diperbaiki adalah pelaksanaan pembelajaran di kelas khususnya pada halhal sebagai berikut:

a. Fase II metode resitasi dengan media gambar : Pelaksanaan tugas I (tugas kelompok).

Dalam kegiatan kelompok melaksanakan tugas : Dalam pelaksanaan struktur dan fungsi tumbuhan, terdapat beberapa siswa yang tidak peduli dan tidak tahu apa yang harus dikerjakan. Sebagian siswa, tidak ikut aktif dalam kerja kelompok tersebut. Sementara siswa yang lain sibuk dengan mengerjakan tugas kelompoknya. Jumlah gambar terbatas, menghambat proses kerja kelompok.

Guru perlu lebih jelas dalam memberikan perintah dalam tugas baik secara tertulis maupun diperkuat dengan lisan, serta memberikan kesempatan kepada siswa untuuk menakan hal-ha yang belum jelas dalam tugas I kelompok. Serta perlu menambah jumlah gambar dengan gambar yang lebih jelas, lebih bagus kulaitas cetaknya.

b. Fase III metode resitasi dengan media gambar: Pertanggungjawaban tugas I (tugas kelompok)

Sebagian siswa yang aktif mempresentasikan hasil dan bertanya jawab dengan kelompok lain. Sebagian siswa lainnya hanya mengikuti tidak memberikan kontribusi pada kelompoknya.

Guru perlu memotivasi siswa yang pasif sekaligus mengatur pemerataan tugas pada tiap kelompok, sehingga mengharuskan tiap anggota kelompok berperan aktif pada fase III, tidak didominasi siswa tertentu.

c. Fase I metode resitasi dengan media gambar: Pemberian Tugas II (tugas Individual)

Pada fase I tugas individual ini mulai muncul hambatan dimana sebagian siswa tidak memangetahui apa yang harus dikerjakan karena pada saat kerja kelompok tidak memperhatian apa yang harus dikerjakan. 
Guru dengan bantuan media gambar perlu memberikan perintah dan menyederhanakan perintah dalam tugas individual dengan jelas apa dan bagaimana mengerjakan tugas, dan memastikan seluruh siswa telah memahami tugas individualnya dan mengerti apa yang harus dikerjakan.

d. Fase II metode resitasi dengan media gambar : Pelaksanaan tugas I (tugas Individual)

Guru memberikan bantuan kepada siswa dalam untuk masalah-masalah yang dianggap sulit oleh siswa, tidak bisa tuntas, karena masih terdapat siswa yang belum jelas apa yang harus dikerjakan.

e. Fase III metode resitasi dengan media gambar: Pertanggungjawaban tugas I (tugas Individual)

Terdapat beberapa siswa yang tidak melakukan presentasi, tetapi hanya mengumulkan tugas ala kadarnya. Pada fase III, guru perlu memotivasi siswa sehingga seluruh siwa mempresentasikan secara lisan. Guru memberikan bantuan, juga perlu menyusun panduan tertulis cara presentasi lisan agar dapat dipahami siswa dengan mudah dan perlu memberikan contoh atau model baik oleh guru maupun oleh siswa yang lain, dengan peer tutoring presentasi.

Dari pelaksanaan tindakan siklus I, hasil yang diperoleh belum mencapai kriteria keberhasilan yang telah ditetapkan sebelumnya, sehingga perlu dilanjutkan ke siklus selanjutnya dengan memperhatikan refleksi siklus I sebagai dasar perbaikan siklus II.

\section{Siklus I}

Perencanaan siklus II dilakukan dengan mempertimbangkan hasil refleksi siklus I. Perbaikan dilakukan sesuai dengan hasil refleksi pembelajaran, dimana modifikasi RPP dititikberatkan pada langkah-langkah yang belum optimal. Pelaksanan siklus II mendapatkan hasil prestasi belajar siswa sebagaimana tertera dalam Tabel 3.

Tabel 1. Prestasi belajar siswa pada siklus II

\begin{tabular}{cccc}
\hline & Pra Siklus & Siklus I & Siklus II \\
\hline Nilai Rata-rata Pos Tes & 75.00 & 78.25 & 85.55 \\
\hline \% Ketuntasan Belajar Klasikal & 78.00 & 80.00 & 90.75 \\
\hline
\end{tabular}

Hasil pos tes siklus II diatas menunjukkan bahwa hasil belajar siswa rata-rata 85.55. Nilai rata-rata ini telah mengalami peningkatan $(+7.30)$ dibanding dengan siklus I. Dan, persentase ketuntasan $90.75 \%$ juga mengalami peningkatan (10.75) dibandingkan dengan siklus I.

Kinerja guru pun mengalami penigkatan yang signifikan, baik kemampuan perencanaan pembelajaran maupun kemampuan pelaksanaan pembelajaran. Skor kinerja guru dapat diamati dalam Tabel 4.

Tabel 2. Kinerja guru pada siklus I

\begin{tabular}{cccc}
\hline & Pra Siklus & Siklus I & Siklus II \\
\hline Kemampuan Perencanaan Pembelajaran & 91.50 & 91.80 & 93.30 \\
\hline Kemampuan Pelaksanaan Pembelajaran & 91.70 & 91.88 & 93.00 \\
\hline
\end{tabular}


Hasil pengamatan kinerja guru menunjukkan skor kemampuan guru dalam perencanaan pembelajaran pada siklus II pada angka 93.30, naik $(+1.50)$ dari skor pada siklus I. Untuk kemampuan pelaksanaan pembelajaran, skor mencapai 93.00 dan meningkat $(+1.42)$ dari siklus sebelumnya.

Pada akhir siklus II perencanaan dan pelaksanaan pembelajaran dapat berjalan sesuai perencanaan dengan hasil telah mencapai indikator kinerja yang ditetapkan. Dengan demikian penelitian ini selesai pada siklus II dan tidak perlu dilanjutkan pada siklus III.

\section{KESIMPULAN}

Dari hasil pembahasan dapat disimpulkan bahwa penerapan metode resitasi dengan media gambar dapat meningkatkan hasil belajar siswa dan kinerja guru di kelas VIII-1 SMPN 4 Bolo semester 1 tahun pelajaran 2020/2021 pada pembelajaran IPA struktur dan fungsi tumbuhan. Keberhasilan pelaksanaan tindakan terletak pada optimalisasi langkah-langkah penting pembelajaran yaitu pemberian tugas individu, kelompok dan pertanggungjawabnnya.

\section{DAFTAR PUSTAKA}

Anitah, Sri. (2009). Media Pembelajaran. Surakarta: Lembaga Pengembangan Pendidikan (LPP) UNS dan UPT Penerbitan dan Percetakan UNS (UNS Press)

Darajat, Zakiyah. (2011). Ilmu Pendidikan Islam. Jakarta: Bumi Aksara.

Djamarah, S.B., \& Zain, Aswan. (2010). Strategi Belajar Mengajar. Jakarta: Rineka Cipta

Hamdayama, Jumanta. (2014). Model dan Metode Pembelajaran Kreatif dan Berkarakter. Bogor: Ghalia Indonesia.

Hardini, I., dan Puspitasari, D. (2012). Strategi Pembelajaran Terpadu (Teori, Konsep \& Implementasi). Yogyakarta: Familia.

Muhibbin Syah. (1995). Psikologi Pendidikan. Bandung; Remadja Rosda Karya

Nasution, S. (2000). Berbagai Pendekatan dalam Proses Belajar Mengajar. Jakarta: Bumi Aksara.

Slameto. (1991). Proses Belajar Mengajar dalam Sistem Kredit Semester SKS. Jakarta: Bumi Aksara.

Subana, M. (1998). Media pembelajaran. Malang: Balai pustaka.

Syaiful, Sagala. (2008). Konsep dan Makna Pembelajaran. Bandung: Alfabeta.

Shalahuddin, Mahfudh. (1987). Metodologi Pendidikan Agama. Surabaya: Bina Ilmu Offset. 